\title{
The African Single Currency: Putting in Place the Missing Link for a Complete Regional Integration Scheme in Africa
}

\author{
Ibrahima Thione Diop \\ School of Economics and Management, Cheikh Anta Diop University, Dakar, Senegal \\ Email: thionediop@yahoo.fr \\ Received 5 September 2015; accepted 24 October 2015; published 27 October 2015 \\ Copyright (C) 2015 by author and Scientific Research Publishing Inc. \\ This work is licensed under the Creative Commons Attribution International License (CC BY). \\ http://creativecommons.org/licenses/by/4.0/ \\ cC) (i) Open Access
}

\begin{abstract}
Facing the threat of globalization, Africa is more than ever forced to lift as soon as possible the factors blocking the integration process which is too long deadlocked. Indeed, Africa remains on the margins of world trade, FDI flows and the ICT revolution, while suffering the brunt of the repercussions of globalization, including the food crisis. This article is a contribution to the issue of economic integration of African countries through the introduction of a single currency. However, the latter seems to be a decisive contribution to permanently overcome the issue of borders but also the divisions in terms of language differences. The main conclusion from this research is that we need to overcome the many constraints faced by the advent of the single currency, which are essentially institutional, but also economic.
\end{abstract}

\section{Keywords}

Integration, Single Currency, Globalization

\section{Introduction}

The idea of Africa Union was not that novel; already in 1912, Marcus Garvey was setting up his "Universal Negro Improvement Association and African Communities League” that he intended to turn into a United States of Africa from 1924 in order to have a fairly representative continent both in its economic, political, cultural, and demographic aspects.

It was in this direction that we must place the emergence of all the Pan-Africanist movements that were created around the year 1945, with Dubois, Lumumba, Kenyatta, Nkrumah, and Cheikh Anta Diop as main leaders. At that time, Pan-Africanism was understood as a doctrine which would enable the realization of the unity of the 
African peoples. In this context, it was also worth noting that it was in the fifth Pan-African Congress in Manchester, in 1945, that the concept of United States of Africa was first mentioned. Independence of African countries from 1957 onwards gave a more political character to the Pan-Africanist idea with the creation of the Organization of African Unity in 1963, the latter being transformed into the African Union since the Lomé summit in 2000. The project of United State of Africa in lethargy had subsequently been reactivated with the accession of President Gaddafi at the presidency of the Union in 2009. During his rule, the charismatic late Libyan Guide planned for the establishment of a military force, a single currency and an African passport. It was clear that this enthusiasm had dwindled today for two reasons: firstly, the reluctance of the majority of African leaders to embrace such a project and the occurance of Arab spring that ended up with the death of President Gaddafi.

However, in the current context of globalization alone where it was widely believed that garthering states into large groups was a valuable asset. The idea of the United States of Africa through enhanced economic integration of different countries might constitute the foundation on which the continent could build upon to setup leverages at the international level. To address the challenges of globalization, it should be noted that the idea of a single African currency could be a great accelerator for the process of setting up the United States of Africa. In this paper, we discussed the arguments in favour of a single currency, as well as the challenges to implement it.

The reminder of the paper was organized as follow. After a brief introduction, another section on the participation of Africa into the world economy follows. Then, the significance of a common currency in African integration process was discussed, referring to theoretical as well as empirical literature. A section on the political arguments for a common currency follows. The Section 5 presented the methodology and results on the impact on a single currency on growth and development. Finally, sections on policy recommendations and conclusions follow.

\section{Africa in the Context of Globalization}

Indeed due to its low integration into global trade and financial networks, Africa has limited the negative consequences resulting from the recession in industrialized countries in recent years. It remains a valid point that Africa still lacks the necessary international economic connections to foster its development process. In this section, we present a set of 4 indicators, to demonstrate how Africa is still marginalized: the share of Africa in World FDI, the share of Africa in global trade, the recurrence of food crises and the delay in the implementation of the Green Revolution, and finally the continent's backwardness in the use of ICT. These four main indicators are relevant signals of how the African continent stand in the world arena, in this context of globalization. The challenges they reveal are likely to be addressed before a credible monetary system can be sustained at regional level.

\subsection{FDI Trends in Africa}

Despite the current importance of international movement of capital in the world, the following observation still holds: Africa often lack resources to finance investments and especially infrastructure. The analysis of the trend of FDI on the continent goes in the same direction. Out of total FDI flows of 1114 billion in 2009, Africa received only 59 billion against 72 billion in 2008 and 63 billion in 2007 which made up 5.3\% of total FDI inflows worldwide in 2009 (see Table 1). In comparison, the trends are around 10.5\% for Latin America and the Caribbean and 20.9 percent for South and Southeast Asia in the same time period. This negative trend is even more marked if one is interested in sub-Saharan African which represents only $1 \%$ of FDI that reached the developing countries in 2009. A detailed analysis shows a concentration of FDI in 2009 in four countries (Angola, South Africa, Egypt and Nigeria). These four countries receive 44\% of FDI to the continent in 2009 [1].

In the same vein, the establishment of new partnerships with emerging countries has changed the configuration of FDI to Africa through the interventions of transnational companies. The activities of these companies represented in 2005/2008, 22\% of the continent FDI against 18\% in the period 1995/1999. For the record, the share of Africa of the total stock of FDI from China went from 1.8\% in 2003 to $4 \%$ in 2008 which still remains low (see Figure 1).

\subsection{The Share of Africa in International Trade}

The various attempts to liberalize international trade according to WTO rules since 1995, have still not improved 
Table 1. Geographic distribution of world FDI flows, 2007-2009 (in billions of dollars and percentage).

\begin{tabular}{cccccccc}
\hline & \multicolumn{3}{c}{ FDI Inflows } & \multicolumn{3}{c}{ FDI Outflows } \\
\cline { 2 - 7 } & $\mathbf{2 0 0 7}$ & $\mathbf{2 0 0 8}$ & $\mathbf{2 0 0 9}$ & $\mathbf{2 0 0 7}$ & $\mathbf{2 0 0 8}$ & $\mathbf{2 0 0 9}$ \\
\hline World & 2100 & 1771 & 1114 & 2268 & 1929 & 1101 \\
Developed countries & 1444 & 1018 & 566 & 1924 & 1572 & 821 \\
Developing countries & 565 & 630 & 478 & 292 & 296 & 229 \\
Africa & 63 & 72 & 59 & 11 & 10 & 5 \\
Developed countries & 68.8 & 57.5 & 50.8 & 84.8 & 81.5 & 74.5 \\
Developing countries & 26.9 & 35.6 & 42.9 & 12.9 & 15.4 & 20.8 \\
Africa & 3 & 4.1 & 5.3 & 0.5 & 0.5 & 0.5 \\
\hline
\end{tabular}

Sources: UNCTAD, 2010.
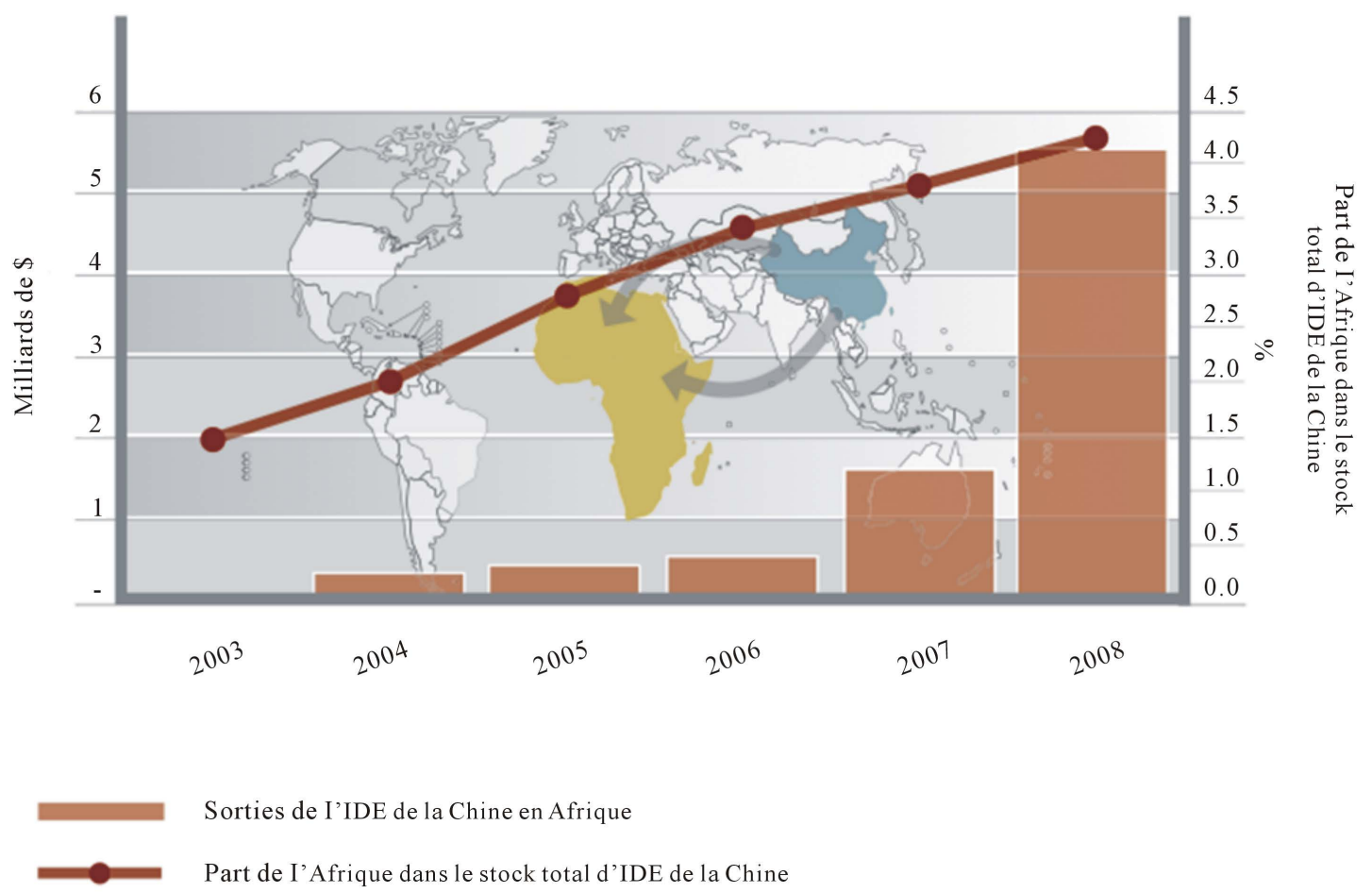

Source: CNUCED (2010)

Figure 1. Direct investment (FDI) from China in Africa.

the ranking of Africa in world trade. The share of Africa in international trade is around 2.8\% [2], despite a strong opening of its markets since the structural adjustment programs of the 1980s. Paradoxically, this greater openness ended up in reducing the share of Africa in world trade, which felt from 4\% in 1980 to $2.8 \%$ in 2008.

To date, the disarticulation and extraversion of African economies are partly responsible of the continent specializing in exports of raw materials and commodities whose prices continue to fall and essentially importing manufactured and food products whose prices continue to rise. Deteriorating terms of trade resulting from such a finding cause the trade balance deficit of the continent to regularly widen. This unfavourable specialization of 
Africa which places contribute to put the continent at the margin of globalization appears clearly through the following UNCTAD statistics in 2008. African exports to the rest of the world are composed by $72 \%$ of fuels and minerals and African imports from the rest of the world by $73 \%$ of manufactured goods. The share of Africa in world exports of manufactured goods went from $1 \%$ in 2000 to $1.3 \%$ in 2008 [3].

The bad position of Africa in world trade is also explained by the difficulties encountered by the WTO to find a compromise about the DOHA Round. Therefore, we continue to observe the pursuit of commercial dumping by developed countries which continue to subsidize their products at the expense of African local productions, thus contributing to impoverishment of African people.

\subsection{Food Crises, Famine and Lack of Green Revolution on the Continent}

The current famine in the continent and the food crisis highlighted the weakness of sub-Saharan Africa in terms of agriculture. Among the causes, we have drought, conflicts, and political instability that drove on the roads of exile hundreds of thousands of Somali, Sudanese and other Africans; also worth mentioning the soaring of oil and food prices but and the absence of a green revolution to boost agricultural yields.

It should be noted that the structural adjustment programs implemented by the IMF in the 1980s, had neglected investment in agriculture. "The share of agriculture in development ODA has fallen from 17\% to 3\% over the last 20 years".

Today, the famine in the Horn of Africa directly threatens the survival of tens of millions of people while Africa is the shelter for $60 \%$ of uncultivated arable land on the planet and has a huge energy potential. A good green revolution associated with sustainable solutions to recurrent crises on the continent could undoubtedly be a lasting solution to hunger.

\subsection{Africa and Use of IT}

By the time the Northern countries show the best penetration rate with respect to the internet, but also experience huge advances in the fields of communication technologies, Africa with its 86 million of users shows an overall penetration rate of $8 \%$ which represents $4.8 \%$ of total users worldwide (UIT2010). Countries which have the best penetration rates in terms of population are Morocco (42\%), Tunisia (33\%), and Nigeria (30\%) (see Table 2).

This low penetration rate on the continent is a blocking factor for the development of some very promising projects. In reality, whatever the projects that will take place today in the continent, it will necessarily have to go through this new technology and this is the case for all sectors of the economy (Nepad 2009).

This reduced level of internet penetration combined with the share of Africa in global research and development budget level (less than 1\%), saddled in a certain way continent's development opportunities.

In total, these four trends allow us to see that Africa does not pull out of the game in today's globalized world,

Table 2. Penetration rate of the internet in various African countries.

\begin{tabular}{cccc}
\hline Country & Number of users (2009) & Population & Penetration rate (2009) \\
Morocco & $13,213,000$ & $31,671,474$ & $42 \%$ \\
Tunisia & $3,500,000$ & $10,589,025$ & $33 \%$ \\
Nigeria & $43,989,000$ & $149,283,240$ & $30 \%$ \\
Egypt & $20,136,000$ & $34,474,000$ & $3 \%, 057,838$ \\
Algeria & 4700000 & 11651858 & $13 \%$ \\
Zimbabwe & $1,423,000$ & $31,367,972$ & $12.2 \%$ \\
Uganda & $3,200,000$ & $39,002,772$ & $10.2 \%$ \\
Kenya & $3,996,000$ & $49,052,489$ & $9 \%$ \\
South Africa & $4,420,000$ & $10 \%$ \\
\hline
\end{tabular}

Source: ITU statistics 2010. 
since in the latter one the most powerful economically are winners. This is what also explains the current constitution of some major economic groups: ASEAN, APEC, NAFTA, Mercosur or the EU. Like these zones and groups of countries, African countries must also explore the path of economic consolidation and the single currency on this path can be a decisive contribution.

\section{The African Currency Systems: A Challenge for the Economic Integration of the Continent}

\subsection{The Theoretical Underpinnings of Economic Integration}

In practice, economic integration refers to a process of reconciliation of several national economies with a view to gradually achieving a single vast economic space within which the different factors of production circulate freely. This economic integration can be achieved in two ways, either by the market or by the production. It should be emphasized that in our case, we focus on the integration by the markets. Several steps are planned in the latter. For Balassa [4], the economic union is the 5th and final phase of integration with the establishment of a single currency. Before that, four intermediate steps should happen first [5]:

- A customs preference area: customs duties are not removed but lowered;

- A free trade area which corresponds to a removal of customs duties among members, but each participating state retains its sovereignty in matters of customs policy;

- A customs union in which we have a complete trade barriers removal accompanied by Common External Tariff (CET) and therefore a loss of sovereignty about customs policy;

- The common market, it comes just after the customs union and is based on two pillars: free movement of goods and of production factors;

- Economic union is the final stage of market integration; there is economic union if we have monetary union.

Before Balassa, a first complete text on integration was directed by Viner [6]. According to Viner, the establishment of a customs union leads to contradictory consequences depending on the parties in place, on the one hand, we have a negotiable instrument for the benefit of partners and on the other hand a diversion effect to the detriment of third countries.

Viner's work was later extended by those of (Lipsey, 1957) and (Meade, 1966). Meade, unlike Viner who had worked only on one product, based his argument on several points around the idea of "inter-commodity substitution" between the different states. According to Meade, substitution between products, combined with the customs disarmament increase the trade creation effect and thus influences indirectly the positive implications of the customs union in opposition to the findings of Viner.

More recent studies have also shown that the establishment of large trade settings may lead them to more profitable horizons either through the allocation effect, or through their growth or accumulation effects.

At the continental level we have works from several organizations based in Africa (UNECA, AfDB, AERC, and AU) in this area. In particular, UNECA and the AU have co-published three reports entitled "state of regional integration in Africa" respectively published in 2004, 2006 and 2008. Furthermore, AfDB published a report on the same issue in 2000 in which it put forward the benefits that Africa could get from integration.

Likewise African experts have developed in recent years a growing body of literature on the issue of integration in Africa, the level of need and difficulty for its implementation [7]. In general, the majority of this literature led to the same conclusion, namely: the positive impact of economic integration on intra-community trade. We now have to analyze if it is actually the case, based on facts.

\subsection{The African Economic Integration to the Test of Facts}

Undoubtedly some progress has been made by some community organizations, indeed, WAEMU and CEMAC now are real economic unions with a single monetary policy, a multilateral surveillance of macroeconomic policies setting, and a CET for WAEMU. However, in the area of stimulation of internal trade and in the goal of achieving sustainable economic growth and the fight against poverty, these regional organisations have not yielded the desired effects. The analysis of the current structure of inter- and intra-community trade on the continent allows us to acknowledge that. To this end, we will take as illustration the case of three regional groups namely ECOWAS, CEMAC and WAEMU.

- The evolution of intra-community trade structure in the 3 groups of countries 
An analysis of statistics shows that the intra-regional trade structure is well below what it is happening in other parts of the world. In this context, out of the 3 groups of countries organized in regional organisations in Africa, WAEMU has the best results. The share of internal trade relative to total exports of the WAEMU moved from $14.5 \%$ in 2008, to $12.4 \%$ in 2009, and decreased to 10.15\% in 2010 (see Figure 2). For ECOWAS, the proportions are $7.39 \%$ in 2009 and 3.21\% in 2010 (see Figure 3); finally CEMAC lags behind, with figures close to $0 \%$ (see Figure 4). The same trend is observed with regard to imports with the best results being obtained by WAEMU 7.48\% in 2008, 6.9\% in 2009 and 5.4\% in 2010 (see Figure 5; Figure 6 and Figure 7).

In comparison, in 2010, the share of internal trade in the EU's total exports is $64.3 \%, 60 \%$ for NAFTA, and $16.10 \%$ for the MERCOSUR (see Table 3).

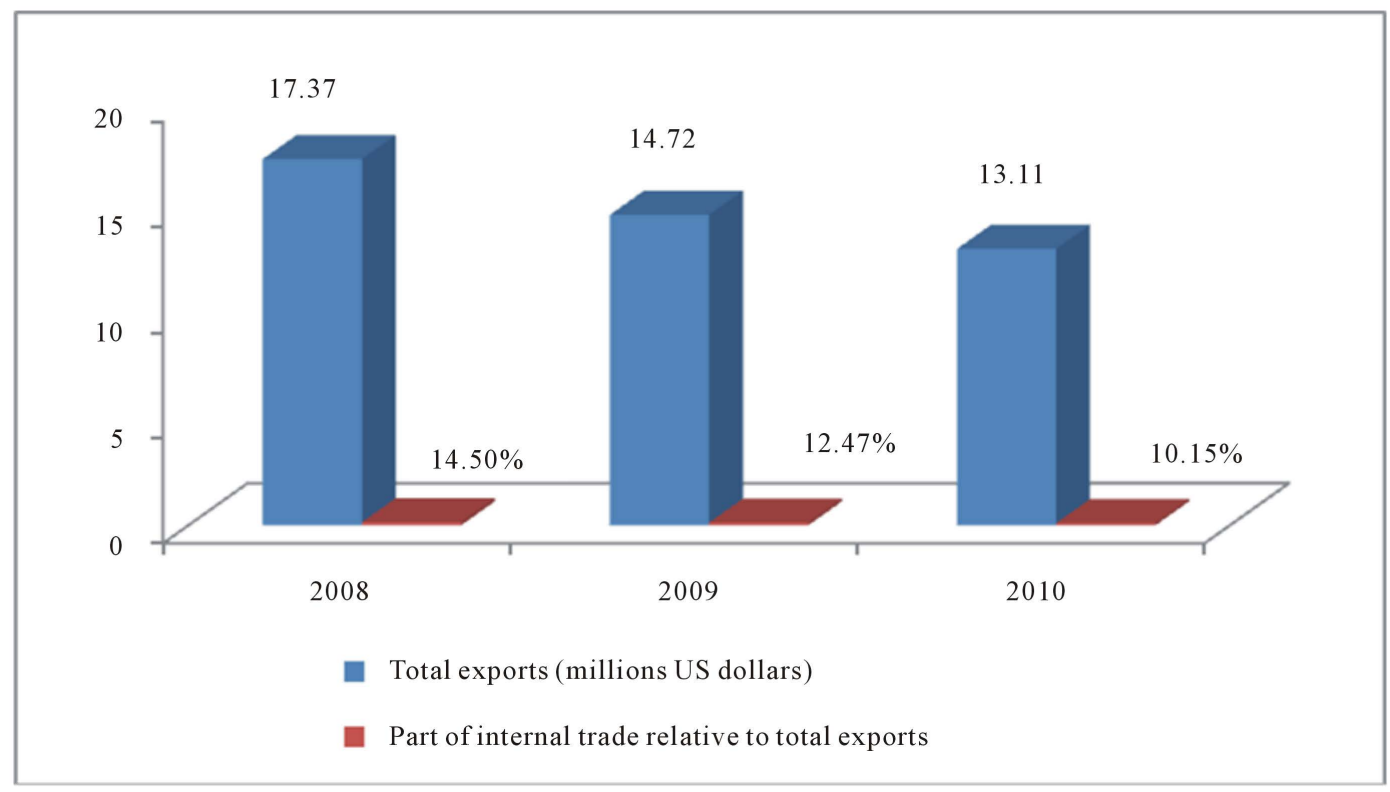

Figure 2. Part of internal trade relative to total exports in WAEMU. Source: Trade Map 2011 and calculation of the author.

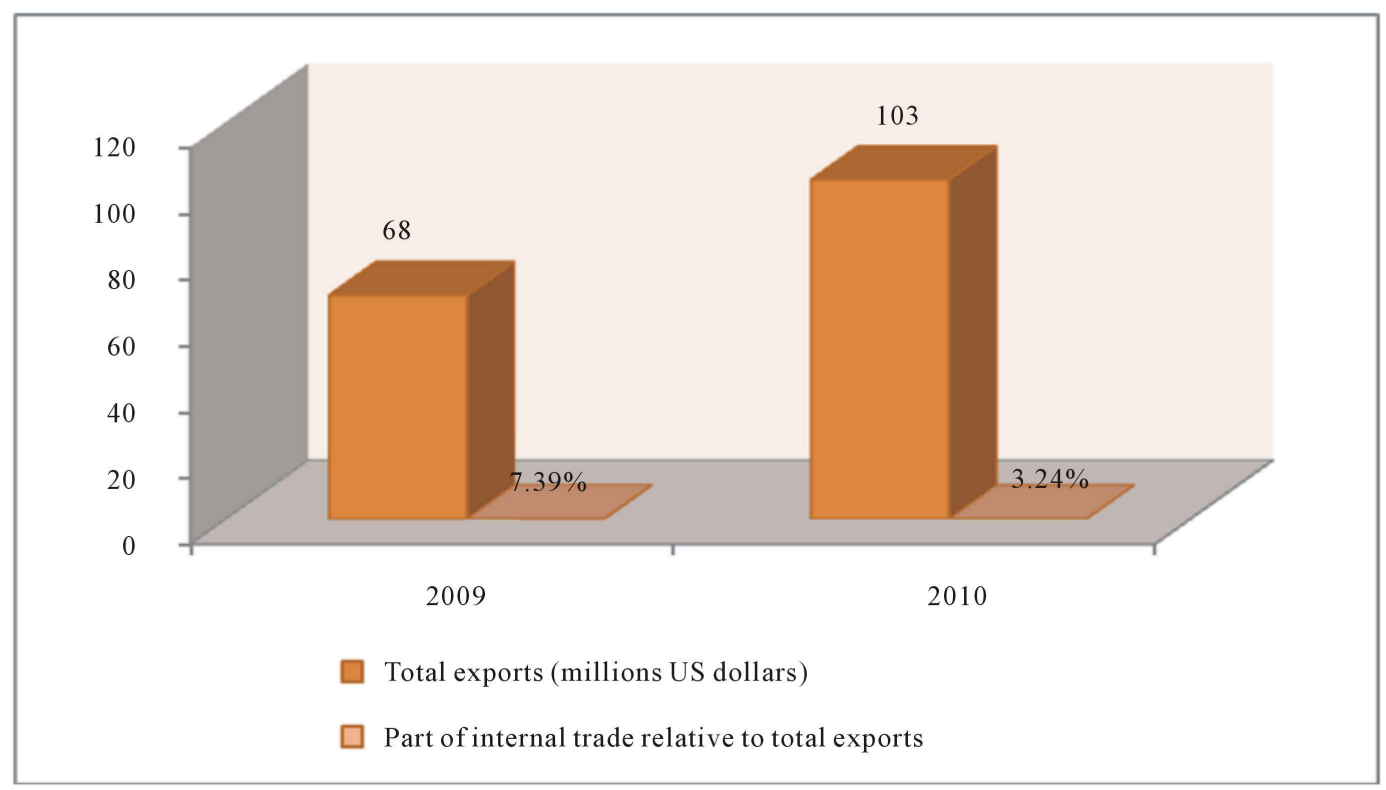

Figure 3. Part of internal trade to total exports of ECOWAS. Source: Trade Map 2011 and calculation of the author. 


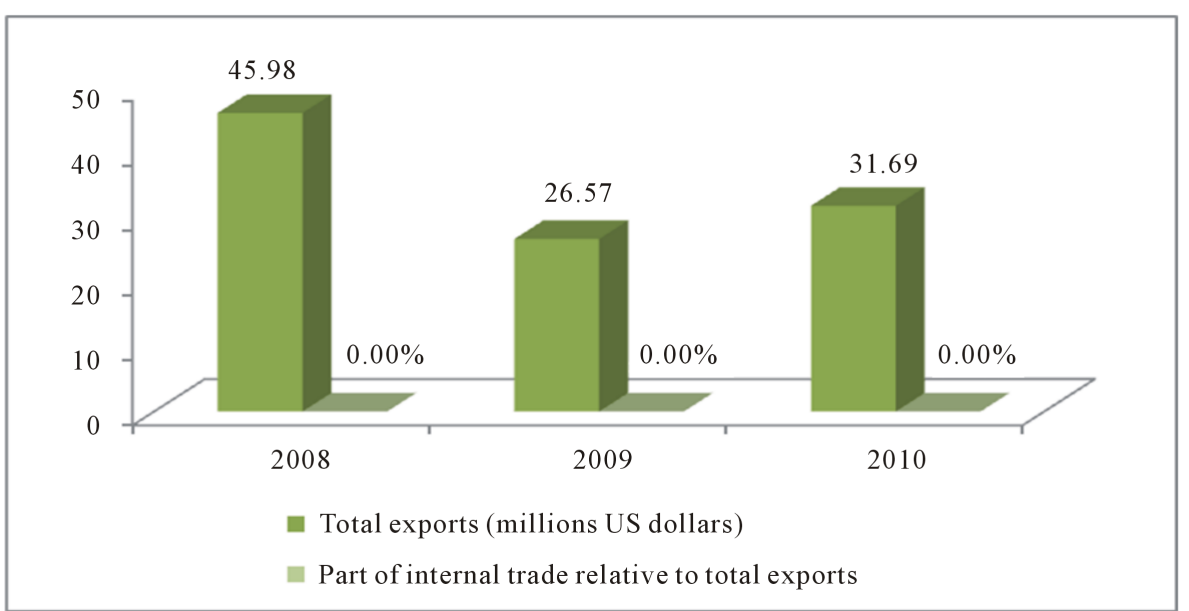

Figure 4. Share of domestic trade to total exports of the CEMAC. Source: Trade Map 2011 and calculation of the author.

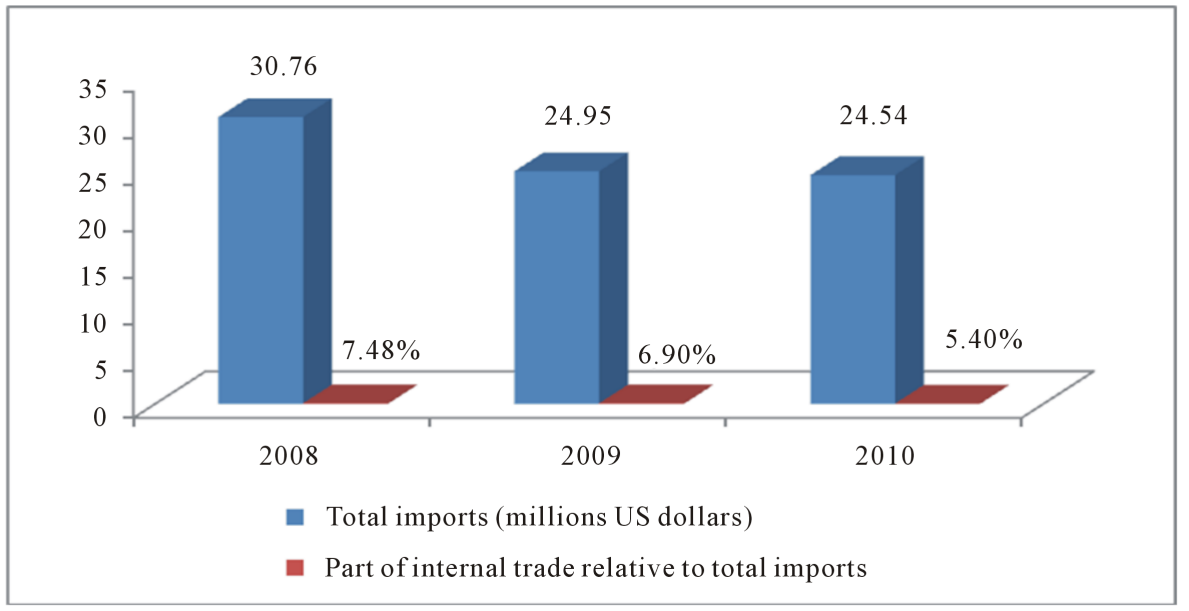

Figure 5. Share of domestic trade to total imports in WAEMU. Source: Trade Map 2011 and calculation of the author.

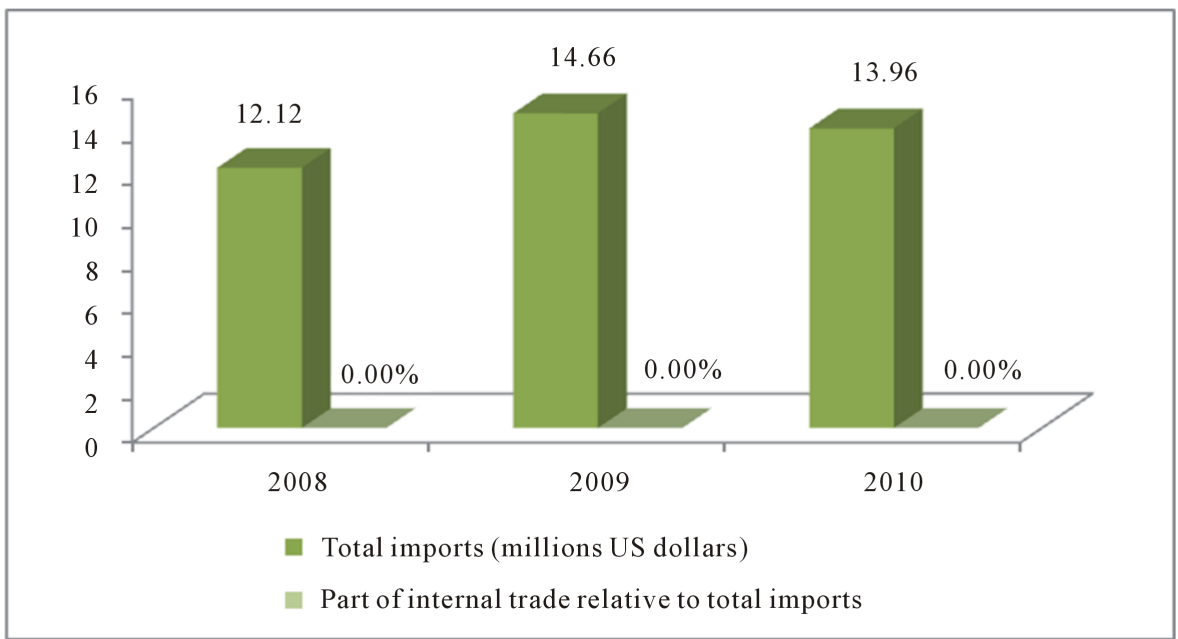

Figure 6. Share of domestic trade to total imports of CEMAC. Source: Trade Map 2011 and calculation of the author. 


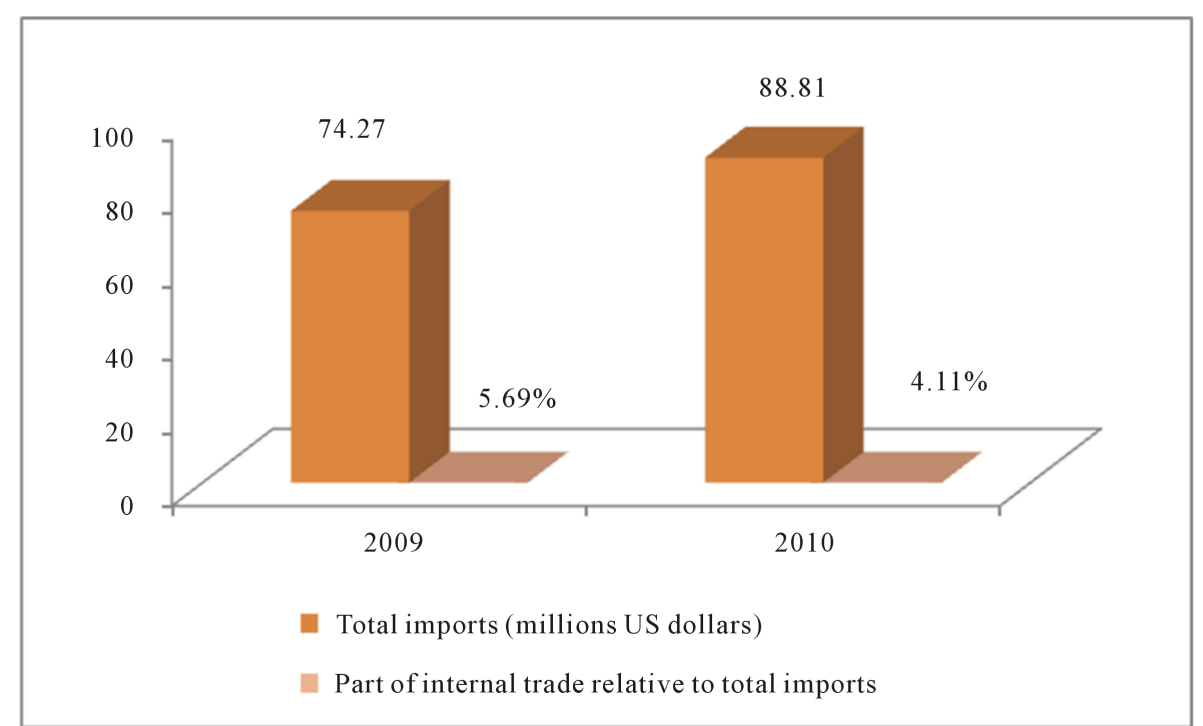

Figure 7. Part of internal trade compared to total imports from ECOWAS. Source: Trade Map 2011 and calculation of the author.

Table 3. Internal trade share in total exports in different regional integration settings.

\begin{tabular}{cccc}
\hline Agencies & 2008 & 2009 & 2010 \\
\hline EU & $66.68 \%$ & $65.94 \%$ & $64.30 \%$ \\
ECOWAS & & $7.39 \%$ & $3.24 \%$ \\
CEMAC & $0.00 \%$ & $0.00 \%$ & $0.00 \%$ \\
UEMOA & $14.50 \%$ & $12.47 \%$ & $10.15 \%$ \\
COMESA & & $8.04 \%$ & $8.77 \%$ \\
MERCOSUR & $14.96 \%$ & $15.06 \%$ & $16.10 \%$ \\
\hline
\end{tabular}

Source: Trade Map 2011 and calculation of the author.

\section{- The changing structure of interregional trade}

According to the latest statistics available in Trade Map (2011), we can say that in the continent, what is valid within the regional communities is generally likely to be valid between communities. In this sense, the share of exports from ECOWAS to CEMAC in the total exports from ECOWAS went from $6.27 \%$ in 2009 to $3.26 \%$ in 2010; the same trend is observed with respect to exports from ECOWAS to WAEMU: 5.54\% in 2009 to 2.85\% in 2010. Business transactions (COMESA, ECOWAS) (COMESA, WAEMU), (CEMAC, WAEMU) give even more catastrophic results. Tables 4-8 show how tiny is the share of interregional trade between economic regional communities within Africa (WAEMU, ECOWAS, CEMAC, COMESA, CEDEAO).

Finally, we thus observed that regional integration in Africa despite the efforts that have been made have not always met the objectives set at the beginning.

Among the obstacles to the development of intra-regional trade, we have the non-diversification of African economies which generally export the same products, and the pervasiveness of the informal sector which masks many commercial transactions. To these obstacles, we could also add the leadership problems between managers that often saddled community initiatives (2 regional stock exchanges in the CEMAC), the infrastructure deficit and the high cost of transport (see Figure 8).

For our study, we will focus especially on the obstacle related to the diversity of the different currencies and their inconvertibility. This obstacle severely limits on one hand the volume of intra-regional trade and on the other hand reduces the competitiveness of African economies, further highlighting the need to have a single currency in Africa. 
Table 4. Export Percentage of CEMAC towards the WAEMU.

\begin{tabular}{cccc}
\hline & 2008 & 2009 & 2010 \\
\hline Interregional trade (in US dollars) & 151,195 & 82,105 & 40,034 \\
Total exports of the CEMAC (in US dollars) & $45,983,397$ & $26,566,708$ & $31,689,736$ \\
Percentage & $0.33 \%$ & $0.31 \%$ & $0.13 \%$ \\
\hline
\end{tabular}

Source: Trade Map, 2011 and calculation of the author.

Table 5. Percentage of imports from COMESA to ECOWAS.

\begin{tabular}{cccc}
\hline & 2008 & 2009 & 2010 \\
\hline Interregional trade & 270,534 & 132,946 & 386,777 \\
COMESA total imports (US dollars) & & $98,440,753$ & $110,232,901$ \\
Percentage & & $0.14 \%$ & $0.35 \%$ \\
\hline
\end{tabular}

Source: Trade Map, 2011 and calculation of the author.

Table 6. Percentage of imports from COMESA to WAEMU.

\begin{tabular}{cccc}
\hline & 2008 & 2009 & 2010 \\
\hline Interregional trade & 222,306 & 99,784 & 27,034 \\
COMESA total imports (US dollars) & & $98,440,753$ & $110,232,901$ \\
Percentage & & $0.10 \%$ & $0.02 \%$ \\
\hline
\end{tabular}

Source: Trade Map, 2011 and calculation of the author.

Table 7. Percentage of imports from ECOWAS to CEMAC.

\begin{tabular}{cccc}
\hline & 2008 & 2009 & 2010 \\
\hline Interregional trade & 210,092 & 189,773 & 527,623 \\
COMESA total imports (US dollars) & & $74,272,098$ & $88,810,270$ \\
Percentage & & $0.26 \%$ & $0.59 \%$ \\
\hline
\end{tabular}

Source: Trade Map, 2011 and calculation of the author.

Table 8. Percentage of exports from ECOWAS to WAEMU.

\begin{tabular}{cccc}
\hline & 2008 & 2009 & 2010 \\
\hline Interregional trade & $5,457,536$ & $3,747,240$ & $2,928,504$ \\
ECOWAS total exports (US dollars) & & $67,663,229$ & $102,593,087$ \\
Percentage & $5.54 \%$ & $2.85 \%$ \\
\hline
\end{tabular}

Source: Trade Map, 2011 and calculation of the author.

\section{Arguments for a Single Currency in Africa}

The arguments in favor of a single African currency were raised for the first time in 1960 within the $\mathrm{OAU}^{1}$, and have gained momentum with the creation of the AACB (the Association of African Central Banks in 1965).

At its 26th ordinary session held in Algiers September 4, 2002, the AACB launched the AMCP (African Monetary Cooperation Programme) with the objective of setting up a currency and a central bank, unique to the continent. To achieve this, the AMCP has established four primary convergence criteria to be followed by at least 51\% of Association members (AACB: Report AMCP 2008):

\footnotetext{
${ }^{1}$ Organization of African Union.
} 


\section{Les prix du transport en Afrique ont tendance a être plus élevés que dans d'autres régions mais les différences au sein de la région sont plus frappantes:}

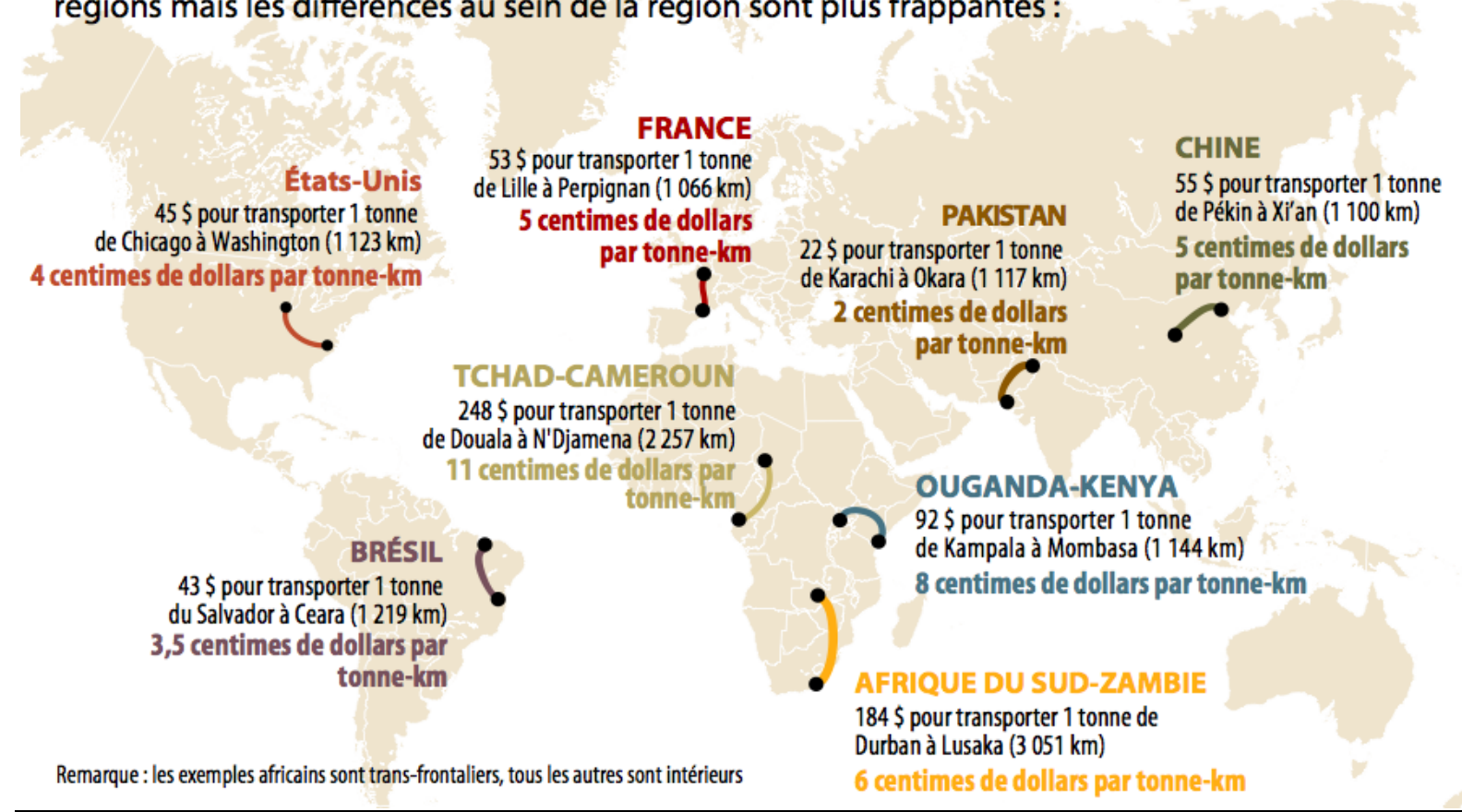

Figure 8. Comparison of the price of transport in some countries. Source: “Africa and the WTO” El Hachemi (Rabat conference in June 2011).

- Overall budget deficit/GDP, excluding grants below 3\%;

- Inflation rate below 3\%;

- Minimizing the budget deficit financing by the Central Bank;

- Higher external reserves or equal to 6 months of imports.

On this road to the single currency, the AACB has divided the continent into five sub-regions and our study focused on the West African part (ECOWAS).

ECOWAS is characterized by the existence of 8 inconvertible currency units whose merger in 2020 in a single regional currency could greatly enhance the economic situation of organization members and stimulate the development of intra-community trade. The beneficial effects of this unique currency include:

- The reduction of transaction costs that would affect production costs in order to improve the economic competitiveness of states;

- A boost and swelling of intra-regional trade through the presence of a single currency facilitating this trade;

- The implementation of orthodox economic and monetary policies due to the constraints from the community (Central Bank in fairly independent regional).

Theoretically, an abundant literature has been devoted to the question of the single currency in ECOWAS, however, it should be stressed that these often lead to opposite conclusions on the impact of monetary union on intra-regional trade. In Mundel [8], the major drawback of a monetary union remains the loss of autonomy of monetary policy.

At the continental level, it should be noted that most of the work on this issue generally lead to positive results [9]. Thus for Masson and Patillo [10], the countries of the franc zone exchange between them 2.2 times more than others; the multiplier for Nitsch [11] being 1.5 .

In the same vein [12] shows that the existence of a monetary union beyond the swelling of regional trade could lead to development of the concept of risk sharing through increased mobility factors of production. This view is widely shared by the employers' federations in the region, indeed, for the vice president of the National Council of Employers of Senegal. "The constitution of the single currency in the ECOWAS will make easier commercial transactions and transfers, facilitate the movement of goods and services, improve the circulation of 
people and expand the financial market by facilitating its growth".

Beyond the stimulation of intra-regional trade, the current emergence of a multipolar international monetary system (dollar, yen, euro) (Agnés Bénassy-Quéré and Ferry, 2011) set the perfect timing for the continent to come together in order to benefit from this multi polarization by setting up its own monetary pole.

In general, all these arguments show clearly the merits of the single currency in ECOWAS and beyond the continent.

Now, how to implement it in ECOWAS?

It will be next to the currency area already existing (WAEMU has 8 member countries sharing the same currency, the CFA franc), to implement the 2nd area called WAMZ ${ }^{2}$ and including NIGERIA, Sierra Leona, Gambia, Guinea, and Ghana. The creation of the WAMZ recently in 2010 was postponed in 2015 due to the difficulties of the 6 countries to meet the convergence criteria; on that date, the WAMZ should adopt its common currency ECO. Then the WAMZ and WAEMU normally extended to two other countries (Cape Verde and Liberia) should merge their two monetary unions in 2020 to give the single currency of ECOWAS. Meanwhile, the basic condition to be met for this process to take is a strict compliance with the convergence criteria issued within the community. "First, a monetary union is the more likely to hold that the countries have similar economic structures, that economic policies are coordinated by governments, and each agrees not to adopt policies that would be harmful to others. We must therefore define an institutional framework that promotes this" [13].

What monetary unit to choose as the single currency in ECOWAS? Some possible scenarios?

Several approaches are possible; must we take all the currency of the most powerful group, which is Nigeria in ECOWAS, with the limit of its political instability? Why not the CFA franc, which is the single currency of 8 states issued by the BCEAO (Central Bank of West Africa) within the WAEMU, which has a tradition of orthodox monetary policy? The concern raised at this level is related to the fact that the CFA franc is under the tutelage of France, acknowledging that a currency cannot be separated to the question of the flag thus the issue of independence. Finally, why not choose the European path, abandoning national currencies and adopting a new monetary unit that would be automatically in place in all member countries and that would compete with national currencies during a given period to in order to finally be the best currency in the sub region [14].

Once the regional currency established and in use, the final phase will be the choice of an exchange rate regime of the new currency which could be fixed or floating relative to international currencies or to a basket of currencies. The difficult choice of this exchange rate regime is the responsibility of monetary authorities who will have to take into account several parameters like: the level of debt, the effects on trade, inflation, growth etc. [13].

A similar approach should be followed in the 4 other sub regions in order to find in each one a sub-regional currency, and the fusion of these sub-regional currencies will finally give birth to the future African single currency.

\section{The Effect of a Single Currency in Africa: Methodology and Results}

The study uses annual data covering the period from 1985 to 2011. Data are for African countries (see annex list). We chose as variables: GDP per capita (GDP/pop), population (pop), exports (X), the direct foreign investments (FDI) and a dummy variable to control FOR membership of a monetary union (MU), which takes the value 1 if the country has a single currency and 0 otherwise. The data are from World Development Indicators (2012) of the World Bank.

The model is inspired by that of Mankiw, Romer and Weil (1992) and Frankel and Rose (2002). We adapted the model to our problem, controlling the effects of monetary union on the increase in per capita GDP of African countries. We assume the following form of the model:

$$
\ln (\mathrm{GDP} / \mathrm{pop})_{i t}=\beta_{1} \ln \mathrm{X}_{i t}+\beta_{2} \ln \mathrm{pop}_{i t}+\beta_{3} \mathrm{MU}_{i t}+\beta_{4} \ln \mathrm{FDI}_{i t}+\beta_{5}+\varepsilon_{i t}
$$

where the variables are transformed in logarithms with the exception of the monetary union.

We use an econometric panel data modelling on a sample of 47 African countries over the period from 1985 to 2011. Our main hypothesis is to measure the impact of monetary union on economic development. We estimate a fixed effects model, random effects, and random coefficients model using the Mean Group estimator of Pesaran and Smith (1995). We adopted the following specifications for the three estimation methods.

\footnotetext{
${ }^{2}$ West African Monetary Zone.
} 
- $\quad$ Fixed effects model (within):

$$
\ln (G D P / p o p)_{i t}=\beta_{1} \ln \mathrm{X}_{i t}+\beta_{2} \ln \mathrm{pop}_{i t}+\beta_{3} \mathrm{MU}_{i t}+\beta_{4} \ln \mathrm{FDI}_{i t}+\beta_{i}+\varepsilon_{i t}
$$

- Random effects model (between):

$$
\begin{aligned}
& \ln (G D P / p o p)_{i t}=\beta_{1} \ln \mathrm{X}_{i t}+\beta_{2} \ln \mathrm{pop}_{i t}+\beta_{3} \mathrm{MU}_{i t}+\beta_{4} \ln \mathrm{FDI}_{i t}+\beta_{5}+\varepsilon_{i t} \\
& \text { where } \varepsilon_{i t}=v_{t}+\gamma_{i t}
\end{aligned}
$$

$v_{t}$ and $\gamma_{i t}$ respectively represent the temporal component and errors of the model.

- Random coefficients model using the Mean Group estimator:

$$
\ln (G D P / p o p)_{i t}=\bar{\beta}_{1} \ln \mathrm{X}_{i t}+\bar{\beta}_{2} \ln \operatorname{pop}_{i t}+\bar{\beta}_{3} \mathrm{MU}_{i t}+\bar{\beta}_{4} \ln \mathrm{FDI}_{i t}+\bar{\beta}_{i}+\varepsilon_{i t}
$$

where $\hat{\bar{\beta}}=\frac{\sum_{i=1}^{n} \beta_{1 i}}{n}, \hat{\bar{\beta}_{2}}=\frac{\sum_{i=1}^{n} \beta_{2 i}}{n}, \hat{\bar{\beta}}_{3}=\frac{\sum_{i=1}^{n} \beta_{3 i}}{n}, \hat{\bar{\beta}}_{4}=\frac{\sum_{i=1}^{n} \beta_{4 i}}{n}$

The Mean Group (MG) does not impose any restriction on the coefficients and can be estimated using a model with random coefficients. The Mean Group estimates the relationship for each country and then evaluates the average of each coefficient.

In Table 9, the coefficients associated with the variable monetary union have the expected signs. Estimates by the methods Within, Between and Mean Group show that all the model coefficients are significant. They are significant in most cases at a $1 \%$ level. From the econometric evaluation, we can observe that an increase in population affects negatively the GDP per capita. This is an important result which reflects a growth dynamic of uncontrolled population in the African context. An increase in direct investment flows into the country a positive effect on GDP per capita, this result suggests that African countries have an interest in establishing a relatively stable macroeconomic framework to attract direct investment sources for economic development through the channel capital flows and technology transfer, as is the case of emerging Asian countries. An increase in the volume of trade increases the wealth of countries through growth driven by exports of goods and services. When there is a monetary union, it promotes economic development, since most of the money circulation area is vast; in addition, it plays its role as a medium of exchange. Among the benefits to this single currency, there may be mentioned:

\begin{tabular}{|c|c|c|c|}
\hline Variables & Within & Between & Mean Group \\
\hline $\operatorname{Ln} X$ & $\begin{array}{c}0.2938^{*} \\
(20.90)\end{array}$ & $\begin{array}{c}0.2475^{*} \\
(18.93)\end{array}$ & $\begin{array}{c}0.5720^{*} \\
(9.29)\end{array}$ \\
\hline Ln pop & $\begin{array}{c}-0.4027 * \\
(-13.61)\end{array}$ & $\begin{array}{c}-0.4093^{*} \\
(-13.59)\end{array}$ & $\begin{array}{c}-0.5676^{*} \\
(-9.38)\end{array}$ \\
\hline $\mathrm{MU}$ & $\begin{array}{l}1.065^{*} \\
(9.90)\end{array}$ & $\begin{array}{c}1.2286^{*} \\
(11.41)\end{array}$ & $\begin{array}{c}0.4804^{*} \\
(4.67)\end{array}$ \\
\hline FDI & $\begin{array}{c}0.00391 * \\
(3.68)\end{array}$ & $\begin{array}{c}0.00317 * \\
(4.47)\end{array}$ & $\begin{array}{c}0,00591 \text { ** } \\
(1,99)\end{array}$ \\
\hline Intercept & $\begin{array}{l}9.711^{*} \\
(18.44)\end{array}$ & $\begin{array}{c}10.9097 * \\
(21.20)\end{array}$ & $\begin{array}{c}5.2884^{*} \\
(8.03)\end{array}$ \\
\hline Number of observations & 1163 & 1163 & 1163 \\
\hline Hausman & $\begin{array}{l}\chi^{2}=79.48 \\
\text { prob }=0.000\end{array}$ & & \\
\hline
\end{tabular}

- The reduction of transaction costs that would affect production costs in order to improve the economic competitiveness of states;

Table 9. Estimate of the determinants of $\log$ ( GDP/pop) of African countries from 1985 to 2011.

$t$ : stat in parentheses for the Within and Between estimators; and z: stat for the Mean group; *significant à 1\% et; ** significant à 5\%. The Hausman test discriminates in favor of a fixed effects model (Within). In the case of the fixed effects model we calculated the average for the intercept. Source: authors computation using Stata 11. 
- A boost and swelling of intra-regional trade through the presence of a single currency facilitating this trade and thus promoting the economic emergence of the continent;

- The establishment of orthodox economic and monetary policies due to the constraints from the community (sub-regional Central Bank independent enough).

\section{Policy Recommendations}

In light of the preceding developments, the single currency appears as an imperative for the development of African countries; however it is not decreed, that means that its requires from the member states to follow certain institutional, political and technical constraint and rules among which we have:

- A strong political will and an acceptance of the abandonment of sovereignty in some areas

In fact, the monetary question refers to the idea of independence and thus sovereignty. Thus, for the single currency to appear on the continent, political authorities, beforehand, should agree to transfer part of their sovereignty to a supranational institution that would be responsible for creating that currency and conduct monetary policy in the union. This Common Central Bank should be independent with respect to the political power, which would give him leeway to conduct orthodox monetary policies, banning for example monetary financing of structural budget deficits.

A strong political will would also mean the end of the race to the leadership in some parts of the continent: in the CEMAC, we have an economic and monetary union with two sub regional exchanges (Yaoundé and Libreville), we also have the introduction of entry visas within the community while the rules strictly postulate the free movement of goods and people.

- Macroeconomic convergence between states

In practice, the viability of a monetary union remains subject to the fulfillment of the convergence macroeconomic between countries, that is to say, the establishment of economic policies pulling in the same direction. "In other words, these policies should be subject to multilateral surveillance by the countries concerned so that some underperformance would not jeopardize the solidarity of the whole. It is this concern that motivated the long process of convergence in which European countries committed before launching their single currency the euro" [13]. In fact, the introduction of a single currency in a totally divergent group pushes the strongest states to destroy the weakest economically. The latest statistics from the AACB show that despite the efforts that have been made in this area, several clamping elements always remain (see Table 10).

- The fight against corruption and the practice of good governance

A credible single currency is not compatible with a high level of corruption. Indeed, the most important current challenge today remains the corruption in the continent, especially in the administration. This one is an obstacle to economic growth, discourages private investment either local or foreign, and reduces the resources available for development .This will feed back negatively on the value of the currency.

- The judgment of the duplication of integration projects in the various sub-regions

In West Africa we have WAEMU and ECOWAS, Central Africa has ECCAS and CEMAC. This duplication of currency areas leads to an increase of fiscal burden on the states on one hand, on the other hand it can undermine the convergence efforts and at the same time be a source of contradictions in the monetary unit objectives at continental level.

Table 10. Number of countries meeting the criteria ranks first 2010.

\begin{tabular}{|c|c|c|c|c|c|c|c|c|}
\hline \multirow[t]{2}{*}{ Subregions } & \multicolumn{2}{|c|}{$\begin{array}{c}\text { Overall budget } \\
\text { deficit/GDP } \leq 3 \%\end{array}$} & \multicolumn{2}{|c|}{ Inflation $\leq 5 \%$} & \multicolumn{2}{|c|}{$\begin{array}{l}\text { Funding budget } \\
\text { deficit by } \mathrm{CB}=0\end{array}$} & \multicolumn{2}{|c|}{$\begin{array}{c}\text { External reserves } \\
\geq 6 \text { months }\end{array}$} \\
\hline & 2009 & 2010 & 2009 & 2010 & 2009 & 2010 & 2009 & 2010 \\
\hline North Africa (6 countries) & 1 & 1 & 3 & 0 & 5 & 0 & 4 & 0 \\
\hline West Africa (15 countries) & 2 & 1 & 10 & 7 & 12 & 12 & 11 & 10 \\
\hline Central Africa (8 countries) & 4 & 4 & 3 & 5 & 7 & 3 & 6 & 4 \\
\hline Southern Africa (11 countries) & 2 & 4 & 1 & 5 & 12 & 11 & 1 & 2 \\
\hline East Africa (11 countries) & 0 & 0 & 2 & 4 & 5 & 5 & 2 & 1 \\
\hline
\end{tabular}

Sources: 2011 AACB statistics. *AACB: Association of African Central Banks. 


\section{Conclusions}

Despite the persistence of the economic crisis on the international level in recent years, Africa has been able to limit the adverse consequences of the recession in the industrialized countries primarily because of its weak integration in international financial and commercial structures. The rate growth in GDP has been able to rebound from $2.6 \%$ in 2009 to $5.5 \%$ in 2010 . However, this level still allows him to achieve the $7 \%$ - $8 \%$ necessary to resolve the issue of the MDGs to fight durably against poverty. Despite the efforts made, Africa still remains on the margins of globalization today.

One of the reasons is the balkanization of the continent with the proliferation of micro states without strong economic fundamentals when other parts of the world gather in large ensembles. In this regard, we find that the question of Africa Union seen from an economic perspective can be an optimal solution to end the crisis on the continent through regional economic integration. In this way, the African single currency can be a decisive contribution to the extent that it will be able to transcend the question of borders but also the divisions in terms of language differences. Indeed, money is a sign of sovereignty, independence and it will make the flag of the future federation of African states. However, single currency does not occur through decreed, thus its introduction and success require the prior satisfaction of certain conditions:

- Strong political will of the different governments to transfer part of their sovereignty to supranational structures;

- An intensification of trade flows between African states and between existing regional economic communities;

- The practice of good governance and the fight against poverty in different states;

- The strengthening of democracy and the establishment of constitutional states on the continent.

\section{References}

[1] UNCTAD (2010) Investment Report in the World. United Nations Geneva.

[2] El Hashimi (2011) Africa and the WTO. Libéralisation commerciale et dynamiques des inégalités. Colloque international de Rabat, Faculté des Sciences juridiques, économiques et sociales, Souissi-Rabat.

[3] UNCTAD (2009) Economic Development in Africa: Strengthening Regional Economic Integration for Africa’s Development. UN Geneva.

[4] Balassa, B. (1962) The Theory of Economic Integration. Allen Unwin, London.

[5] Diouf, M. (1983) Economic Integration in Africa. NEAS Edition, Dakar.

[6] Viner, J. (1950) The Problem of Customs Unions. The Carnegie Endowment for International Peac.

[7] Dieye, C.T. (2010) Quel future pour l’intégration et le commerce intra régional en Afrique de l’Ouest. Rapport Enda SYSPRO Dakar.

[8] Mundell, R. (1961) A Theory of Optimum Currency Area. AER No. 51.

[9] Madariaga, N. (2010) Mesure et évolution récente de l'intégration commerciale en zone franc. Revue Macrodev, AFD, November 2010, No. 1.

http://www.afd.fr/webdav/site/afd/shared/PUBLICATIONS/RECHERCHE/Scientifiques/Macrodev/01-Macrodev.pdf

[10] Masson, P. and Patillo, C. (2004) Une monnaie unique pour l’Afrique. Finances et Développement, IMF. https://www.imf.org/external/pubs/ft/fandd/fre/2004/12/pdf/masson.pdf

[11] Nitsch, V. (2004) Comparing Apples and Oranges: The Trade Effect of Currency Union Multilateral Is Small. In: Alexander, V., von Furstenberg, G.M. and Mélitz, J., Eds., Monetary Unions and Hard Pegs: Effects on Trade, Financial Development and Stability, Oxford University Press, New York, 89-100. http://dx.doi.org/10.1093/0199271402.003.0006

[12] Nubukpo, K. (2010) Monetary Policy and Regional Market Development in West Africa: The Challenges of the CFA Franc and the Challenges of a Single Monnaie in ECOWAS. Enda Review SYSPRO Dakar.

[13] Dufrénot, G. (2010) Towards Anic Currency for ECOWAS Countries. Grain of Salt News No. 51.

[14] Von Hayek, F. (1986) Denationalisation of Money. London Institute of Economic Affairs, Special Papers No. 70. 